\title{
The Particularity of Military Logistics System and Its Development Focus
}

\author{
LU Xinghua \\ Army Engineering University-Shijiazhuang Campus \\ Shijiazhuang, Hebei, China \\ lu-xh163@163.com
}

\author{
MA Zhixin \\ Army Engineering University-Shijiazhuang Campus \\ Shijiazhuang, Hebei, China \\ 907229834@qq.com
}

\begin{abstract}
Modern military logistics system is a new system brought about by information technology and new military reform, and is one of the important fields of military modernization. Based on the concept of military logistics system, this paper analyzes the particularity of military logistics system and points out key directions and fields of military logistics system construction in the information age. In fact, to study the construction of the military logistics system, we must also attach great importance to relevant policy research and standardization research. This is an important prerequisite and foundation for the construction of the military logistics system.
\end{abstract}

Keywords-Military logistics system; Particularity of military logistics system; Military logistics development; Development Focus

\section{THE CONCEPT AND SYSTEM COMPOSITION OF MILITARY LOGISTICS}

The concept of logistics originated in the United States in the 1930s, and the original meaning was "physical distribution" or "goods delivery". According to people's understanding of the connotation of logistics, the definition of logistics in different countries is also different. In the 1990s, the American Logistics Management Association updated the definition of logistics to: Logistics refers to a part of the process of planning, executing and controlling the supply chain for the efficient and effective flow and storage of goods, services and related information from source to use point to meet customer needs [1]. Logistics Terminology Standard defines logistics as: Logistics is the process of integrating the functions of transportation, storage, loading and unloading, packing, circulation processing, distribution, information processing and other functions to achieve the user's requirements during the flow of goods from the supply location to the receiving location [2]. As an important social service industry, logistics is not only widely used in the civil field, but also has become an important part of the military logistics system in the military field, and the concept of military logistics and military logistics system are derived from it. In general, military logistics means that military materials needed for military forces to live, train, perform duties and operations in peacetime and wartime are eventually sent to the troops and consumed and used through the stages of financing, transportation, packaging, processing or production, warehousing and supply, and the entire process of their space transfer is realized [3]. Conceptually speaking, both military and civilian logistics are the whole process of physically moving materials from the supplier to the person who needs them, and the spatial movement of materials is accomplished through transportation, loading and unloading, warehousing, packaging, processing and supply, therefore, the essence of military logistics and civil logistics is the same [4]. However, due to the particularity of the military field, the military logistics system and the civil logistics system must have certain differences. Specifically, the military logistics system is based on the country's economic conditions, military technical level, information technology foundation, Battlefield environment, combat style, weather conditions, laws and regulations, and technical standards [5]. It consists of several sub-systems, such as military logistics facilities, military logistics equipment, military logistics information, military logistics command, military logistics personnel, and military logistics and finance, which are interconnected, interdependent, interdependent, and interactive [6]. It has a specific function to enable military materials to reach the demand area(target area) quickly, accurately, reliably, safely and cheaply from the supply area(source area), and can adapt to the requirements of the military to perform diversified military tasks under information-based conditions. Figure 1 briefly illustrates the relationship between the military logistics system and its related elements. 


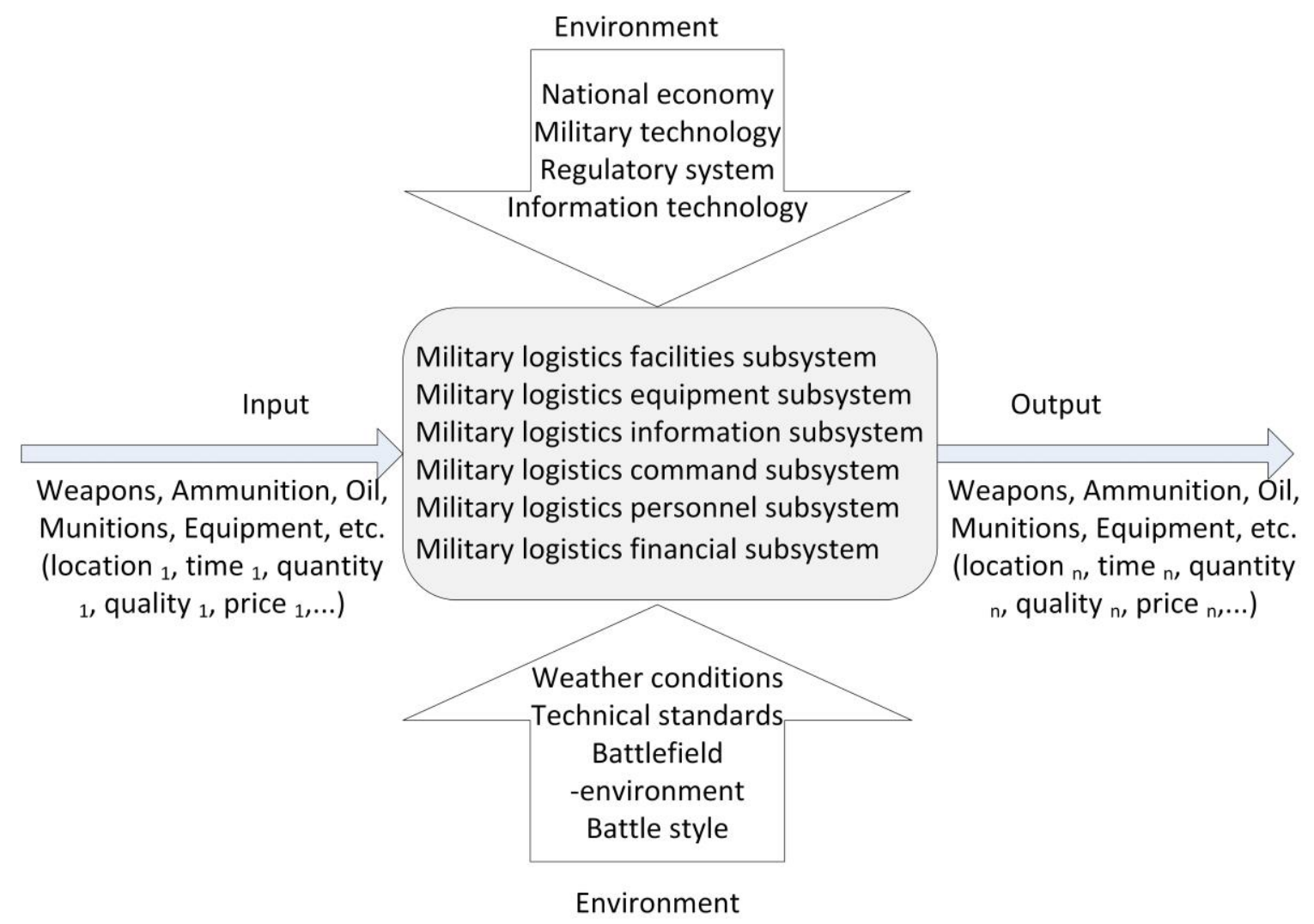

Fig. 1. Relationship between military logistics systems and their related elements

As can be seen from Fig. 1, the specific functions of the military logistics system are reflected in the quantity, quality, and space-time changes that have occurred after the military materials have been processed by the system, although the input and output elements of the system are equipment, weapons, ammunition, fuel, munitions, maintenance equipment and so on, but in the output end of the system, the membership right, place, time, quantity, quality, utility and so on will be different from the input, the quantity may be reduced, the quality may become worse and the utility will become larger. In structure, the military logistics system is a network system with warehouses and transportation hubs as nodes, transportation lines as connections, and materials, various loading and unloading equipment, and transportation forces as elements. Among them, the warehouses include material storage facilities such as the state, the army, the localities, enterprises, etc.; the transportation lines include highways, railways, waterways, routes, etc.; materials include materials stored in warehouses, ports, airports and materials in transit; loading and unloading equipment include fixed and mobile equipment; transportation forces include all kinds of road vehicles, railway vehicles, ships, aircraft and so on. In operation of system, the military logistics system belongs to the process system, it includes the financing, packaging, handling, loading and unloading, transportation, storage and distribution of military materials. The number of links that make up the military logistics process system depends on the scale and level of the problems analyzed, and type of decision maker. Generally speaking, the more macro-level logistics is, the more logistics links the process system contains, whereas the less it is. However, no matter the military logistics process system is large or small, it should include at least two or more than two logistics operation links, a single operation link is not a logistics process system.

The structure of the military logistics system can be described in Figure 2. 


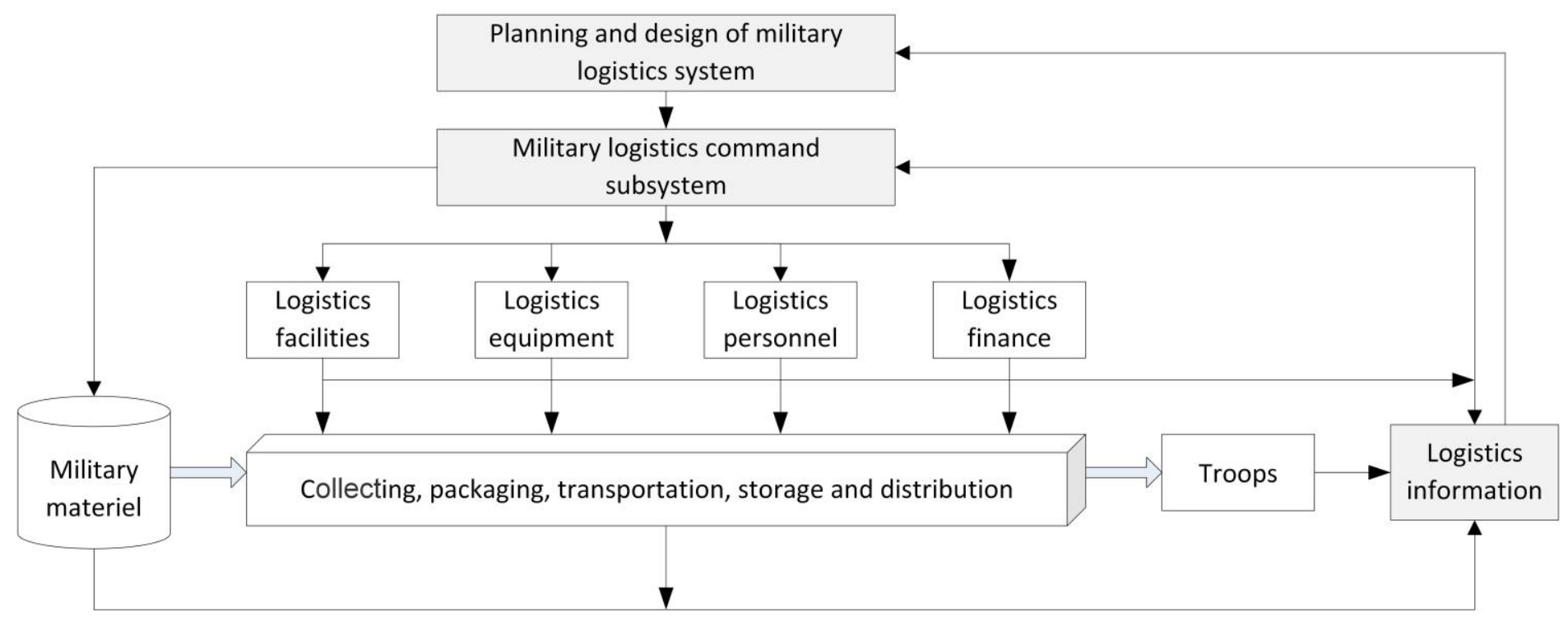

Fig. 2. Structure of the military logistics system

From Figure 2, it can be seen that the military system engineering analysts plan and design the military logistics by obtaining the information of the military logistics system, and provide the results of the planning and design to the military logistics command subsystem for the decision-makers to refer. After the decision maker chooses the scheme, it controls the material, facilities, equipment, personnel and financial subsystem through the command subsystem, and then controls the operation of military logistics, and realizes the function of the military logistics system. Logistics information system plays an important role in the whole large scale system. System planning and design need information, military logistics management decision requires information, and military logistics operation control requires real-time information.

The military logistics command subsystem needs to determine the scheme by obtaining information on military requirements, material supply information, military logistics facilities, equipment, personnel, finance, etc., and based on the decision support information provided by system analysts. Then through the command subsystem to control the military logistics facilities, equipment, personnel, and finance of the four subsystems, military supplies to the troops. The logistics information system is the most important and active subsystem in the military logistics system, it is closely connected with all the other subsystems of the system, and plays a "nerve" role in the operation of the military logistics system. Figure 2 also clearly shows the relationship between the functional subsystems of military logistics and the elements of military logistics process. The process of military logistics includes military material raising, packaging, handling, handling, transportation, storage, distribution and other links, this process is controlled by the function subsystem in the military logistics system. Although the analysis object of the military logistics system is the logistics process, the object of its planning, design and system diagnosis is the sub-systems of military logistics command, information, facilities, equipment, personnel and finance. The scientific and reasonable military logistics process is realized through the synergy of the military logistics function subsystem. The effectiveness of the military logistics system can be tested by the military logistics process index.

\section{THE PARTICULARITY OF MILITARY LOGISTICS}

Military logistics can be divided into three situations: peacetime, emergency and wartime. Military logistics in peacetime mainly refers to the logistics produced by the army in its daily work and training. Emergency military logistics refers to the logistics generated in the peacetime to cope with sudden natural disasters, anti-terrorism, stability maintenance, and other events using military force. Military logistics in wartime refers to logistics that occurs under war conditions. Compared with civil logistics, military logistics has obvious particularity.

\section{A. The suddenness of task}

Suddenness is determined by the particularity of military action. Before the occurrence of logistics, civil logistics always goes through a "prelude" process, such as planning, procurement negotiations and signing contracts. And military logistics will depend on the time of military action. Once war or emergency mission occurs, military logistics will be generated when military action is needed. For war action, military action must be secretive and sudden, and the time, direction and scale of military action will change at any time, which requires the rapid response ability of military logistics.

\section{B. The planning of operation}

The significant difference between military logistics and civilian logistics is that the operation of military logistics system is carried out in strict planning and planning. In terms of the variety, quantity and reserve layout of military materials, it is necessary to strictly measure and implement the plan management according to the requirements of the army's combat readiness, training and living. In the procurement, 
production, storage, transportation and other links of military materials, it is also necessary to strictly plan and manage the military materials according to the characteristics of military materials, and organize the implementation according to strict management level, strict rules and regulations, and standardized operation procedures.

\section{The confidentiality of information}

Confidentiality is another distinctive feature of military logistics that distinguishes it from civil logistics. In the process of logistics, there is usually no confidentiality requirement for civil logistics. In order to expand the commercial effect, logistics companies sometimes deliberately disclose logistics information. And military logistics is different. The variety, direction and volume of military materials are important components of military actions. In order to achieve the suddenness of military intentions, the information of combat materials must be kept secret during the logistics process.

\section{The importance of warehouses}

Military materials, especially military equipment, are mostly stored in national defense warehouses. In civil logistics, warehouses emphasize the "Circulation" function. In military logistics, the warehouse focuses on the "reserve" function of military equipment. Large-scale defense warehouses play the role of supply support "base" rather than "station" or "hotel". As a military material reserve and supply support base, the defense warehouse connects the source of military supplies in the front section, the rear end is connected to the demand of the troops, and logistics is often "stopped" here for a long time. From the function and role of national defense warehouse, we can see that the role of warehouses in logistics is more important, it must be able to "store", "keep", "loading and unloading", "transportation and distribution", and can also carry out "circulation processing" and "secondary packaging".

\section{E. The uncertainty in logistics quantity}

In the war, the warring sides will exert their wisdom limit and take all the means that can be taken to achieve the purpose of war. Therefore, the battlefield situation is always complicated and changeable, which determines the uncertainty of military logistics. In the future information war, the battlefield space will be expanded, the time will be shortened, the front and rear boundaries of the battlefield will be blurred, and the offensive and defensive transitions will be accelerated, which will make the flow direction and flow quantity of military logistics more variable. Although there is also a certain degree of uncertainty in civil logistics, its flow direction and flow quantity are relatively easy to predict and judge.

\section{F. The risk of process}

Logistics risks arise from all aspects of the logistics process. The risks of civil logistics mainly come from poor management, weather changes, uncertain traffic conditions, outsourcing and so on. Compared with civilian logistics, military logistics risks include not only the risk factors of civilian logistics, but also the risks of enemy reconnaissance and attack, moreover, the risk of the same type of risk elements in military logistics is far greater than that of civilian logistics. Under the conditions of war, the distribution centers, transportation lines, and transportation forces of military materials will all become targets of the enemy. Therefore, logistics risks must be fully considered in the design of military logistics. It is a contradiction to avoid risk and improve the logistics efficiency. How to choose the logistics process in wartime and effectively improve the guarantee ability are the important issues that must be studied in the military logistics theory.

\section{THE DEVELOPMENT FOCUS OF THE MILITARY LOGISTICS} SYSTEM

In the 21st century, with the rapid development of information technology and the continuous updating of military material management ideas, especially with the changes in the characteristics of modern information warfare, the military logistics must meet the requirements of "quick response, flexible and reliable operation, safe and efficient operation, timely and accurate supply, and adequate and effective supply", and realize the "visual" and "controllable" total assets of the military logistics system, so that military logistics to achieve the goal from semi-mechanization, mechanization to informatization and precise supply support. For this reason, the development and construction of military logistics today will mainly focus on the following seven aspects.

\section{A. The command and control automation}

In the 21 st century, military logistics is characterized by high speed, high strength and high consumption, command and control of the military logistics system is required to be able to analyze the demand of military materials in timely and accurately, make the supply support plan quickly and carefully, and implement the command and decision-making flexibly and correctly. Command and control automation of military logistics system is the use of networked communication means and computer-centered automation means, and is the establishment of military logistics management information systems(MIS), decision support systems(DSS), and expert systems(ES), and is to build the $\mathrm{C}^{3} \mathrm{I}$ of military logistics system in an all-round way, and is to realize the timely collection of support information, the rapid processing of support data, the correct decision-making of the support plan in military logistics system, and to significantly improve the efficiency and correctness of the decision-making plan. The command and control automation of the military logistics system is the lifeblood of the entire military logistics system, and it is the bridge connecting the various support links and terminal equipment of the military logistics system. 


\section{B. The support information visualization}

The support information visualization of the military logistics system is to use comprehensively various coding technology and barcode technology, IC card recognition, magnetic strip recognition, sound recognition, visual recognition, radio frequency recognition, biometric recognition and optical character recognition technology and other automatic recognition technology, and to rely on traditional wireless and wired communication, microwave communication, mobile communication, satellite communication, optical fiber communication and other communication transmission technologies, and to obtain timely and accurately information flow of military logistics systems composed of resources such as variety, quantity and quality of military materials, the consumption of military materials, war damage, etc., and various logistics nodes, docks, supply stations, and field warehouses, through command and control automation system and military data communication network, to realize the direct communication and command and control of support information, so as to reduce the transmission time of support information to almost zero, realtime decision-making is achieved, and transparent control, situational awareness and precise management of military logistics system are realized. ${ }^{[7]}$

\section{The storage complete set}

The complete set of military logistics system storage is to use strategic and campaign reserves of military materials as a source, adopt the method of collective packaging, and use prepositioned storage means to achieve the standardization of military logistics system storage quantity, the scientific form of storage, and the rationalization of storage layout.

It is to calculate, count and distribute military materials in wartime, and transport and other circulation support work. It is pre-decomposed into the construction of the military material logistics system in peacetime to save combat conversion time; Shorten the supply distance and reduce the supply link; Save supply time and reduce the task of sending military supplies; Increased efficiency in the distribution of military materiel and increased force mobility; It will create conditions for the loading and unloading mechanization, transportation threedimensional and distribution dynamics of the military logistics system, and lay a foundation for improving the rapid support ability of the military logistics system. It pre-decomposes the work of calculating, counting and distributing, and transporting military materials in wartime to the construction of the military logistics system in peacetime, so as to save battle conversion time, shorten the supply distance, reduce the supply link, save supply time, reduce the task of sending military supplies, increase efficiency in the distribution of military materiel and increase force mobility, and. It will create conditions for the loading and unloading mechanization, transportation three-dimensional and distribution dynamics of the military logistics system, and lay a foundation for improving the rapid support ability of the military logistics system.

\section{The packaging containerization}

The packaging containerization of the military logistics system is to adopt advanced, economical, safe and efficient containerization technology to realize the Collection packaging of military materials, so as to adapt traditional containers or bulk military materiel to the new structure of rapid supply and support of the military logistics system of the twenty-first century, it lays the foundation for mechanized loading and unloading and three-dimensional transportation of military logistics system. The packaging containerization of the military logistics system should be based on pallet assembly and package assembly, relying on local containers of 5 tons, 10 tons of containers and special containers for the military, and vigorously develop the technology of integrated loading, unloading, storage and transportation, and establish systematically a collection packaging model that meets the military logistics system of the 21 st century.

\section{E. The mechanization of loading and unloading}

The mechanization of loading and unloading is the use of loading and unloading machinery to loading and unloading the military material for complete sets or assembly packages, in the course of all supply guarantees, such as routine receipt and delivery, loading at the time of flat combat, and reprinting before and during war, such as pallet pullers, stacking trucks, forklifts, cranes(that is, cranes), field forklifts, and container loading and unloading tools to replace the loading and unloading mode of carrying shoulders, it can improve the labor intensity of workers, and reduces the needs of workers and improves operational efficiency. The construction of loading and unloading mechanization in military logistics system has always been a weak link and bottleneck factor in the military logistics system, which has an important influence on improving the capability of the military logistics system. In order to accelerate the construction of loading and unloading mechanization in military logistics system, we should take advantage of the advanced technology of modern basic industry and the successful experience of civil logistics, vigorously develop the integrated loading and unloading technology which integrates loading and unloading, storage and transportation to shorten the gap with the civil logistics, and finally achieve the complete set of functions, the highest overall efficiency and the optimal ratio of cost efficiency.

\section{F. The three-dimensional transport}

The military logistics system realizes finally its supply support function through the space displacement of the transportation support link. Because the modern local war has concentrated on the latest weapons and equipment with high mechanization automation and great destruction and destructive power, the direct consumption of military materials and the loss of military materials caused by the destruction of the enemy will increase sharply. In the face of huge military material consumption, only through timely, effective, safe and accurate military material transportation support, can we meet the needs and give full play to the operational effectiveness of the troops. The three-dimensional transportation of military logistics system is to use advanced aircraft, air drop and other means of transportation, and the 
comprehensive use of railway, highway, waterway and air transport capacity, manpower and animal power, and so on, and utilize a variety of motorized transportation tools such as self-loading and unloading trucks, self-unloading trailers, armored track-type transport vehicles, trains, ships, and aircraft, and through land, waterway, aviation, and other effective ways, and carry out large-scale, long distance, high speed and multi direction transportation support to military materials, and lastly remote mobile support, vertical support, accompanying guarantee and direct guarantee are realized from ground, water and air to enhance the mobility of military logistics system.

\section{CONCLUSIONS}

Modern military logistics system is a new system brought about by information technology and new military reform, it is one of the important fields of military modernization. Based on the concept of military logistics system, this paper analyzes the particularity of military logistics system and points out the key directions and fields of military logistics system construction in the information age. In fact, to study the construction of the military logistics system, we must also attach great importance to relevant policy research and standardization research. This is an important premise and foundation for the construction of the military logistics system. In today's era, the military logistics system is not developed in isolation. The continuous improvement of civilian logistics facilities and means, and the active use of intelligent technology in the field of civil logistics have had a profound impact on the development of military logistics systems. How to make effective use of the advantages of civil logistics in the application of military logistics system, such as the outsourcing of military logistics, is a real problem worth studying. Within the military, with the advancement of military logistics joint logistics support, how to realize the integration of logistics support for various arms and services is also a very real problem. To make breakthroughs in these areas, we must vigorously promote the standardization research and construction of logistics system. The standard is for the purpose of obtaining the best order, to make common provisions on the activities or their results, by consensus and by the rules, guidelines, or special documents approved by the recognized institutions. Because modern military logistics is highly coordinated on the basis of highly specialized division of labor, therefore, in order to ensure a high degree of coherence between the various links in logistics and between various departments, it is necessary to establish a supporting system of policies and standards in addition to the need to use modern information technology. The military logistics standard system should take the military logistics system as the research object, the focus is on regulating the technical performance, operations, and information transmission of facilities and equipment within the system, so as to ensure the military logistics resources are compatible with each other and the military logistics activities are smoothly connected.

\section{REFERENCES}

[1] Wang Zongxi. Military Logistics [M]. Beijing: Tsinghua University Press. 2005: 45-49.

[2] Jin Xiuman. Re-understanding of the Military Logistics System [J]. Journal of the Logistics Command College, 2009,(4): 31-34.

[3] Jin Xiuman, Zhu Xiaohua, Wang Hongzhi. Study on Military Logistics Dynamic Model [J]. Military procurement and logistics, 2007,(3): 61-64.

[4] Zhou Xizhao. Logistics System Engineering [M]. Shanghai: Shanghai University of Finance and Economics Publishing House, 2013:39-43.

[5] Wang Zongxi. Construct a High-Performance Military Logistics System [J]. Storage Management and Technology, 1998, (4):59-62.

[6] Wang Feng, Chen Jiangdali, Peng Liang. Military Logistics [M]. Beijing: China Material Publishing House, 2003:109-121.

[7] Tian Xuejun. American Logistics and Informatization Situation and Its Enlightenment [J]. China Logistics and Enterprise, 2004(7): 36-39. 